\title{
ON THE CHOICE BETWEEN CAPITAL AND LABOUR MOBILITY
}

\author{
Jagdish N. BHAGWATI
}

Columbia University, New York, NY 10027, USA

T.N. SRINIVASAN*

Yale University, New Haven, CT 06520, USA

Received August 1982, revised version received December 1982

\section{Introduction}

Trade theorists, since the pioneering work of Kemp (1966). have considered the question of national advantage from international factor mobility by considering only one factor to be so mobile.

Kemp analyzed elegantly the question of optimal policies in $2 \times 2 \times 2$ model and showed that, since monopoly power could exist in both the goods and factor markets in consequence of international capital mobility, the optimal policy intervention would generally involve two policy instruments: tariffs (-cum-subsidics) on goods and duties(-cum-subsidies) on international capital flows. Jones (1967) subsequently extended Kemp's argument to the secondbest context by examining the optimal level of one of these instruments when the other was arbitrarily set at zero. Elsewhere in this issue, Brecher (1983) shows, in an elegant and original contribution, that the Jones policy problem is, in fact, a third-best, rather than a second-best, problem, as generally believed, and that if only one of the tariff and capital mobility taxes(-cumsubsidies) can be used, it is generally possible to improve welfare further by admitting an altogether different, domestic policy instrument: namely a production or consumption tax-cum-subsidy, as the case may be. ${ }^{1}$

\footnotetext{
*The research of Bhagwati was supported by the German Marshall Fund Grant No. 1-34015. The problem analyzed in the paper was posed in Bhagwati (1979) and an early ingenious and neglected analysis in Ramaswami (1968) was noted by Bhagwati. We have profited greatly from these contributions; also from reading Webb (1970), Ramaswami (1970) and a recent paper of Calvo and Wellisz (1983) on this problem.

${ }^{1}$ This result is in consonance with the results of Bhagwati, Ramaswami and Srinivasan (1969) for the case without international capital mobility; but the consonance is 'intuitive' only after the result was established for the case with international capital mobility.
} 
Interesting as this line of analysis is, it is based on two critical assumptions:

(1) that the other country is passive in the face of policymaking by one country, exactly as in the orthodox analysis of optimal policy intervention which assumed that the foreign offer curve facing a country is given exogenously; and

(2) that the other factor of production (labour, in the usual $2 \times 2 \times 2$ analysis of international capital mobility) is internationally immobile.

The former assumption is traditional in the international-economictheoretic literature on optimal policies for open economies, with such classic exceptions as the theory of optimum tariffs with retaliation, as developed by Scitovsky (1942), Johnson (1953-54) and later writers.

But the latter assumption is more crippling in ruling out of consideration the fact of international labour mobility and, indeed, its systematic regulation by the policy instrument of immigration restrictions by nation states since the beginning of the twenticth century. As it happens, an important and novel question that has appeared in the policy context is precisely whether it would be to the national advantage of a capital-abundant country to export capital (à la the Marxist-Leninist prediction of monopoly capitalism) or to import labour (as countries such as West Germany did through their gastarbeiter programs in the postwar period). Bhagwati (1979) raised this question in the Ramaswami Memorial Lecture as follows:

The problem is best illustrated with regard to the migration of labor to the United States. As you are doubtless aware, the USA has an enormous inflow of illegal migrants who come in principally from Latin America and, in turn, mostly from Mexico. The immigration barriers have not been successful in stemming this inflow which is variously estimated as having led to a stock of close to 10 million illegal immigrants. In response to this inflow, and as a result of the growing and effective trade union pressures, the Carter administration has had to take cognizance of the problem in its social, legal and economic dimensions. In this context, it has occasionally been suggested that the United States ought to encourage the flow of funds, both private and public, in order to create more prosperity in Mexico to reduce the economic disparities that fuel the illegal exodus.

With regard to the deployment of public funds, in the form of foreign assistance, towards this end, it is of course possible to think of this as a bribe to the countries of illegal emigration to use their control machinery more effectively to stem the illegal migration. For, democracies such as the United States, with their strong civil-libertarian and liberal lobbies, are not in a position to start shooting happily at the illegal migrants and the effectiveness of controls on migration may be enhanced from the emigration end by offering suitable incentives to these countries of emigration. 
But, even if this is true, the fact remains that the principal motivation behind such a policy remains the creation of more job opportunities and improved standards of living in the poorer countries of emigration.

But this immediately suggests a related and interesting question. Suppose that wc have a capital-rich country, the United States, and a capital-poor country, Mexico. Assume that the United States can unilaterally decide on two alternative courses of action, both assumed to be feasible: i.e., that it allows its capital to migrate to Mexico, while effectively closing the border to immigration; or alternatively that it prohibits capital outflow but permits immigration of Mexican labor. If then the United States can also choose optimal taxes and subsidies on such factor flows, so that we wind up comparing optimal ways of choosing between the two forms of mobility, which would be to greater national advantage?

This precise formulation of the analytical question, which Ramaswami (1968) happened to pose in a neglected and ingenious contribution utilizing a one-good model, is however analogous to the Kemp-Jones-Brecher analysis in that it treats international labour mobility as symmetric in its implications with international eapital mobility, the only difference being that one may yield higher welfare to the policymaking country. However, the two types of international mobility are asymmetric in two important respects.

First, while it is generally possible to tax capital outflows from a country, the reverse taxation of labour coming into a country by the country of 'immigration' is not such a straightforward matter. As the discussion of the proposal of Bhagwati's (1978) to 'tax the brain drain' made manifest, the (discriminatory) taxation by the country of residence of foreign labour is fraught with numerous difficulties from legal, constitutional, human-rights and political standpoints. ${ }^{2}$ Therefore, the economic theorist must rank-order, as in Ramaswami's (1968) classic paper, not just the optimal taxation of outflowing capital by the capital-rich country with the optimal taxation of incoming (foreign) labour by the capital-rich country. A realistic policy comparison must augment the policy set to include therefore the rankordering of policies where the discriminatory taxation of incoming foreign labour is not allowed, thus permitting an asymmetry in the tax-jurisdictional scope in regard to the taxation of one's capital outflow and the taxation of the other's labour outflow into one's country.

\footnotetext{
${ }^{2}$ Many of these difficulties are discussed in Bhagwati and Partington (1976). However, they do not extend to the country of nationality exercising income tax jurisdiction over its citizens resident abroad. What we are discussing in the text is the country of residence exercising its own tax jurisdiction in an overtly discriminatory fashion on foreign residents: e.g. by levying a 10 percent surcharge on the income of foreigners resident in the country. The economics of the former question has been explored in a Symposium in the Journal of Public Economics (vol. 18, no. 3, 1982) by Bhagwati (1982), Bhagwati and Hamada (1982), Baumol (1982), Mirrlees (1982) and Wilson (1982a, 1982b).
} 
Second, international labour mobility raises the added difficulty that, once labour crosses national borders, we have to worry about which country's welfare it ought to be included in. As Bhagwati (1979) has argued, the investment of capital abroad does not affect, in principle, the group over which 'national' welfare will be defined. By contrast, the 'migration' of human beings raises the question: Which national group do the migrants belong to? There is no universal answer to this question. Migrants who are temporary, because of explicit rules in that regard as with gastarbeiters in Western Europe and imported workers in the oil-rich Middle East, evidently will classify as part of the 'national' population in the country of origin. But what of permanently emigrating nationals? If they do 'go away' for good, there is a convincing case for treating 'national' welfare as defined only over 'those left behind'. On the other hand, as seems to be the case today with a large fraction of the highly skilled migration from the less developed countries to the developed countries, if this migrant population is characterized by retention of ethnic ties to the country of origin, a high frequency of visits and even continuation of citizenship status in many cases, the fact of permanent migration (embodied in the holding of immigrant visas) is thoroughly compatible with the analyst including such migrants in the definition of 'national' welfare for the country of origin. When we rank-order the optimal taxation of capital outflow with the optimal taxation of labour inflow, as in Ramaswami (1968), we are treating the foreign labour as part of the foreign country's welfare function. But then we need also to consider the possibility that it may be regarded, after immigration, to be part of one's own welfare.

In the analysis below of the choice between capital and labour mobility from the viewpoint of national advantage, therefore, we will be mindful of these important asymmetries introduced by international labour, as against capital, mobility. We will utilize Ramaswami's one-good model, which eliminates the necessity to look simultaneously at the implications in the goods market that lead to the complexity of the Kemp-Jones-Brecher analysis. Using this model, we will consider the welfare-effects in a twocountry model where the capital-rich country uses (1) a free international factor mobility policy, (2) a quota policy in regard to capital outflow and labour inflow, (3) an optimal capital-outflow tax policy, and (4) alternative discriminatory tax policies on inflow of labour. Evidently, policies (1) (3) do not, but policies (4) do, require having to differentially tax 'immigrant' labour; and where the differential taxation of foreign labour is inadmissible, the rank-ordering of policies will have to exclude policies (4). We will principally consider, in section 2 , the case where welfare of immigrant labour is considered part of only foreign welfare. ${ }^{3}$ In section 3 , however, we briefly

\footnotetext{
${ }^{3}$ Also see the analysis in Calvo and Wellisz (1983) which considers these issues utilizing the Ramaswami one-good model as well. Of interest also is the exchange between Ramaswami (1970) and Webb (1970).
} 
indicate the complexities introduced in the case when this cannot be assumed.

\section{Immigrants' welfare part of only foreign welfare}

Consider now a one-good model with two countries, America (A) and Mexico (M), with two factors of production $(K$ and $L)$, where A has initially a higher endowment ratio of capital such that $\left(K_{\mathrm{A}} / L_{\mathrm{A}}\right)>\left(K_{\mathrm{M}} / L_{\mathrm{M}}\right)$. The technology is, moreover, considered, as in Ramaswami, to be identical between $\mathrm{A}$ and $\mathrm{M}$ and characterized by the usual restrictions, such as constant returns to scale and the Inada conditions.

Given this specification, consider fig. 1. The overall capital and labour endowment of America and Mexico determines the size of the box diagram. $E$ represents the initial endowment point, such that $O_{\mathrm{A}} N$ and $O_{\mathrm{A}} Z$ are the capital and labour endowments, respectively, of America, and $P N$ and $Z Q$ of Mcxico. The diagonal represents, given identical technology, the contract

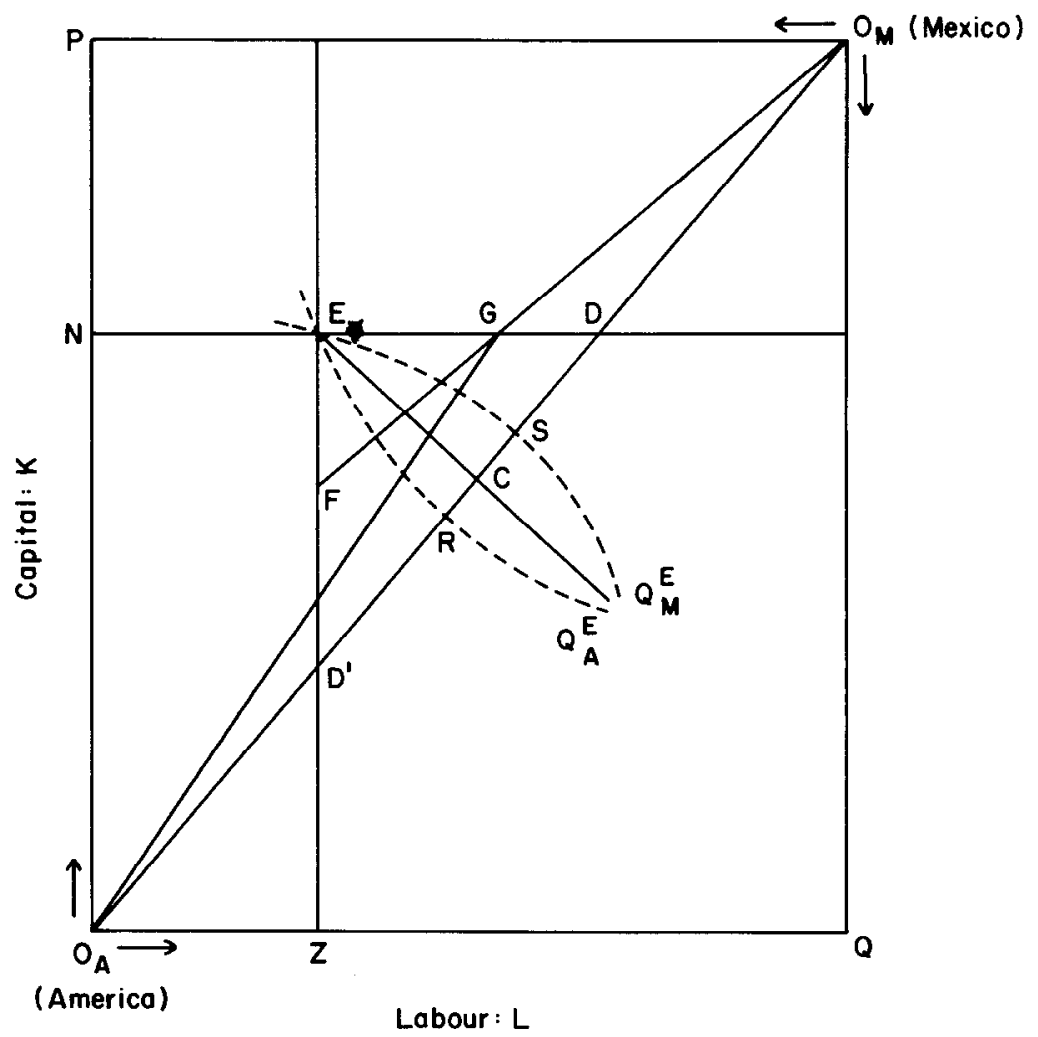

Fig. 1 
curve for the world endowment. Any point of allocation of world factor supply on this contract curve is evidently Pareto-efficient; along the diagonal, the wage-rental ratio is invariant. $E$, on the other hand, is off the contract curve and yields, in an initial autarkic (i.e. no international factor mobility) situation, $Q_{\mathrm{A}}^{E}$ output for America and $Q_{\mathrm{M}}^{E}$ output for Mexico. Since we have constant returns to scale and identical world technology, we can equally measure the outputs along the diagonal and read the output of America as $O_{\mathrm{A}} R$ and of Mexico as $O_{\mathrm{M}} S$. Finally, consider throughout that America is the policymaking country and that Mexico can take no policy action at all.

\subsection{Free factor mobility}

Suppose now that America allows free factor mobility. It is evident then that the triangle $E D D^{\prime}$ defines the range of possible equilibrium outcomes for factor distribution among the two countries. Thus, $E D^{\prime}$ of capital could flow out of capital-rich America and that would equalize wage-rental ratios in the two countries at $D^{\prime}$; or $E D$, Mexican labour, could flow into America and again wage-rental ratios would be equalized identically at $D$; or combinations of such capital outflow from, and labour inflow into, America could lead the world-allocation of the overall factor supply to equilibrium anywhere along $D D^{\prime}$ at the same wage-rental ratio.

What about the welfare impact? It is immediately clear that, in all cases, America goes from $O_{\mathrm{A}} R$ to $O_{\mathrm{A}} C$ and Mexico from $O_{\mathrm{M}} S$ to $O_{\mathrm{M}} C$, so that America gains $R C$, Mexico gains $C S$, and the world's gain is $R S$. To see this, take the case where $E D$, Mexican labour, moves into America. America's GDP then is $O_{\mathrm{A}} D$. However, Mexican labour $E D$ earns $C D$, since the equilibrium wage-rental ratio is $E C$. Therefore, America's GNP is $\left(O_{\mathrm{A}} D\right.$ $-C D)=O_{\mathrm{A}} C$, implying a gain of $R C$. By identical reasoning, Mexico's GNP goes from $O_{\mathrm{M}} S$ to $O_{\mathrm{M}} C$, representing a gain of $C S$. Identically, these results follow when the factor reallocation settles anywhere else on $D D^{\prime}$. Especially, if American capital of amount $E D^{\prime}$ flows out, American GDP will be $O_{\mathrm{A}} D^{\prime}$; the earnings of $E D^{\prime}$, American capital in Mexico, will be $D^{\prime} C$, and hence American GNP will again be $O_{\mathrm{A}} C$; American gain from the autarkic position will again be $R C$; and Mexican gain can similarly be shown to be $C S$.

\subsection{Quotas on factor mobility}

Consider next the possibility of utilizing quantitative restrictions by America on (i) immigration of Mexican labour and on (ii) outflow of American capital. [Note that this policy does not involve discriminatory. taxation of either factor.]

Of course, if only one of these policies is utilized, the other factor will move internationally until the world equilibrium winds up along $D D^{\prime}$, 
creating the same outcome as under free factor mobility. Suppose, however, that both quotas are utilized simultaneously. Take then two polar cases: (i) no capital outflow is permitted and labour inflow is restricted below $E D$; and (ii) no labour inflow is permitted and capital outflow is restricted below $E D^{\prime}$.

In the former case it is readily seen that, given the capital immobility, the restriction of labour inflow below $E D$ is welfare-worsening for America. For, if more Mexcan labour comes in, it produces increasing gain to America by driving down its own reward due to diminishing returns: and this continues until the inflow is stopped by wage equalization between both countries at $D$. Therefore, any immigration restriction that restricts the Mexican labour inflow below $E D$ will reduce American gain below $R C$ and reduce world gain below $R S$ by pushing the world allocation off the contract curve $O_{\mathrm{A}} O_{\mathrm{M}}$. As for Mexico, it will also gain from the restricted outflow of its labour to America and its gain may be less or greater than or equal to $C S$ (which is the gain from unrestricted outflow up to $E D$ ).

Consider now the latter case, where the labour flow is eliminated but America does not allow full outflow of American capital by amount $E D^{\prime}$ to reach the contract curve. We then have an asymmetric result for America. For, from the American standpoint, it will pay America to restrict the outflow of capital to the point where the marginal return abroad equals its marginal product at home. This optimal export restriction on capital outflow, say $E F$, will then produce for America a gain exceeding $R C$; the world will gain less than $R S$; and Mexico will gain less than $C S$.

Thus, we have the asymmetrical result that, if only labour inflow is to be permitted, capital-rich America ought to allow it to the free-immigration level; whereas, if only capital outflow is to be permitted, America ought to restrict it. This asymmetry, of course, follows from the fact that American capital is essentially driving down its reward in Mexico and hence its marginal return is below its average return there so that restriction of capital outflow below the free-outflow level is desirable; whereas when Mexican labour is coming into America, it is Mexico that is correspondingly losing (part of its) gains from the labour outflow to higher-wage America, and therefore it is America that is gaining, so that American advantage (though not Mexican advantage, of course) is best pursued by America letting Mcxican labour come in freely!

The welfare outcomes under these alternative policies are readily illustrated by reference to the familiar marginal-product curves in figs. 2 and 3 for the capital-flow and the labour-flow cases, respectively. In fig. 2 the marginal product curves for Mexico and America are drawn as $W Y$ and $N Y$, with equalization of the marginal products and corresponding rentals at outflow $E D^{\prime}$ from America to Mexico. Optimal capital export from America's standpoint is, however, $E H$, and is derived by taking the curve $W T$ marginal to $W Y$ and its intersection with $N Y$, in the usual manner. Then, recalling the 
measures of gains in fig. 1 for the different policies as $R S, C S, R C$, etc. and, examining fig. 2, we can infer the results shown in table 1.

Similarly, for the labour immigration case, using fig. 3 , we readily see that American advantage is maximized at $Y$, at which $E D$ level of freeimmigration labour inflow yiclds a gain to America worth WMY: a gain that can only be reduced if the labour inflow is reduced by an arbitrary quota such as $E a$, which then yields American gain worth only $W X V$. Thus, we can infer the results in table 2.

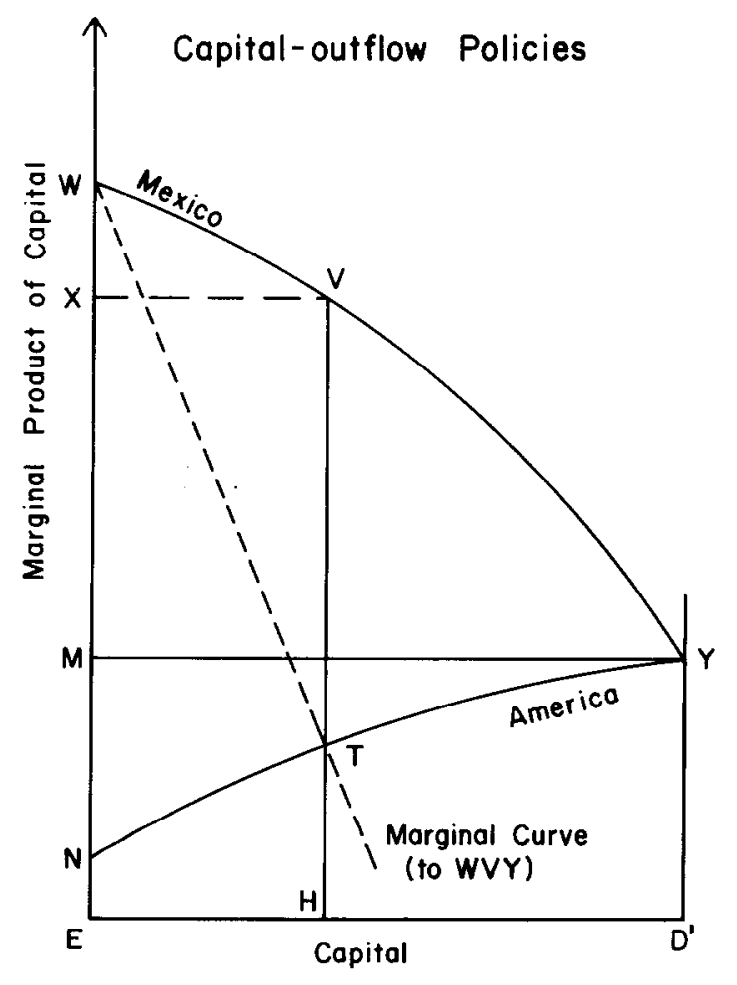

Fig. 2

But the rank-ordering of policies just derived depends critically on the assumption that America cannot levy discriminatory taxation on foreign labour as an instrument of policy. This yields an advantage, as we have just seen, to capital-outflow vis-à-vis the labour-inflow policies in America when it maximizes its national advantage. But as soon as we admit the possibility of levying taxation on immigrant (but not on national) labour, this advantage gets reversed, as we note immediately below. 


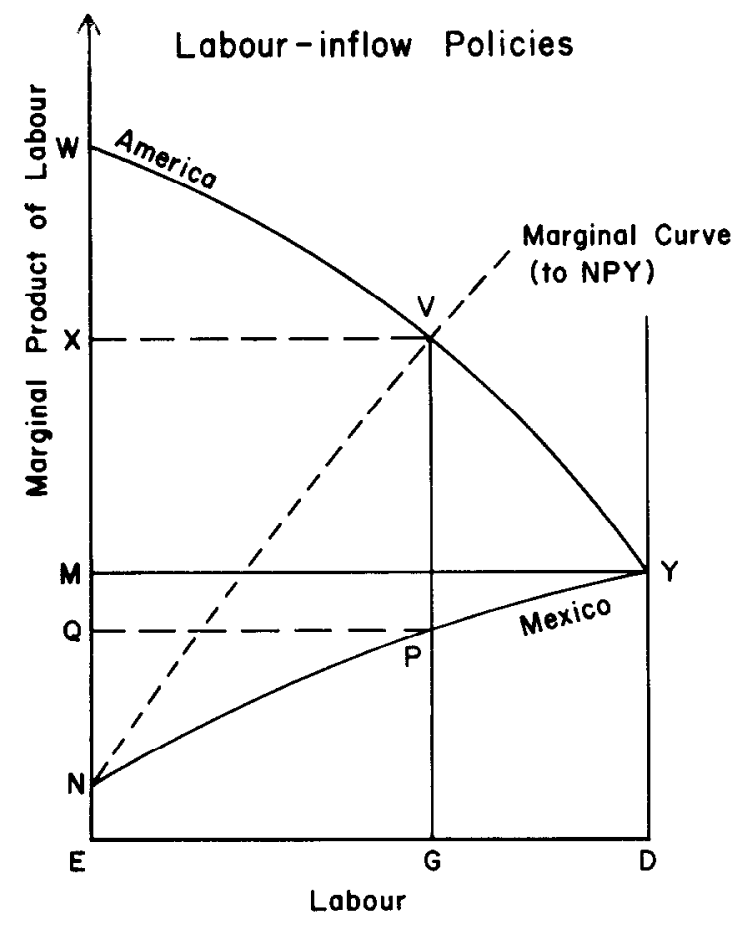

Fig. 3

Table 1

Capital outflow policies.

\begin{tabular}{|c|c|c|c|c|}
\hline \multirow[t]{2}{*}{ Gain } & \multicolumn{2}{|c|}{$\begin{array}{l}\text { World-efficient } \\
\text { capital outflow } \\
\left(E D^{\prime}\right)\end{array}$} & \multicolumn{2}{|c|}{$\begin{array}{l}\text { Optimal-for-America } \\
\text { capital outflow } \\
(E H)\end{array}$} \\
\hline & Fig. 2 & Fig. 1 & Fig. 2 & Fig. 1 \\
\hline 1. World gain & $W N Y V$ & $(=R S)$ & $W V T N$ & $(<R S)$ \\
\hline 2. American gain & MNY & $(=R C)$ & $X V T N$ & $(>R C)$ \\
\hline 3. Mexican gain & $W M Y$ & $(=C S)$ & $W V X$ & $(<C S)$ \\
\hline
\end{tabular}

\subsection{Discriminatory taxation of foreign labour}

First, we should note that discriminatory taxation of American capital outflow by America produces an identical result as the American restriction of such outflow which we just discussed. 
Table 2

Optimal labour inflow policy.

\begin{tabular}{lll}
\hline & $\begin{array}{l}\text { World-efficient and } \\
\text { optimal-for-America } \\
\text { labour inflow } \\
(E D)\end{array}$ \\
\hline Gain & Fig. 3 & Fig. 1 \\
1. World gain & $W N Y$ & $(=R S)$ \\
2. American gain & $W M Y$ & $(=R C)$ \\
3. Mexican gain & $M N Y$ & $(=C S)$ \\
\hline
\end{tabular}

\subsubsection{Optimal tax on labour inflow}

On the other hand, the discriminatory taxation of Mexican labour by America enables America to gain more than it would simply by restricting Mexican labour inflow to a level identical to that produced by the tax policy. For example, in fig. 3, if Mexican labour inflow is restricted to $E G$ by a quota, it will yield a gain $W X V$ to America. But if this inflow is achieved by a tax on Mexican labour that effectively shifts the Mexican supply curve $N P Y$ up to cut $W V Y$ at $V$, the American gain will be $W V P Q(>W V X$ by $X V P Q$, the tax revenues from the Mexican inflow of $E G$ at tax rate $V P / P G$ ). And, for an optimal tax policy by America, this gain for America will exceed that under free immigration (i.e. $W M Y$ ). That is to say, if $V$ were obtained, and the corresponding optimal tax rate was set by taking the marginal curve to $N P Y$ and intersecting it with $W V Y$, we would be equating the marginal cost of Mexican labour supply to its marginal product in America and thus showing $V P / P G$ as the welfare-maximizing American tax on Mexican labour.

Such an optimal labour-inflow tax policy by America will therefore yield a gain exceeding $R C$ in fig. 1 , while it will get the world allocation off the contract curve and reduce world gain below RS. Mexico, on the other hand, will find its gain reduced below $C S$.

Ramaswami (1968) ingeniously showed, moreover, that such an optimal tax policy on inflowing Mexican labour would produce a greater gain to America than the optimal tax-cum-restriction on American capital outflow.

The policies being compared appear, at first blush, to be impossible to compare analytically. Ramaswami, however, managed to rank-order them with the following remarkable argument. Following him, consider the hypothetical experiment where, starting from the optimal capital-export policy of export of American capital at level $E F$ in fig. 1, America brings this capital back home while simultaneously permitting only $E G$ amounts of Mexican labour into America. By construction, then, the Mexican capitallabour ratio at $F$ and $G$ is the same. Therefore, if we now envisage America producing the single good in this model with two techniques, one technique 
using $O_{\mathrm{A}} Z$ units of American labour and $Z F$ units of American capital, and the other technique using $E F$ units of American capital with $E G$ units of immigrant Mexican labour, America will earn the same income as with the optimal export of $E F$ units of capital. For, the earnings of these $E F$ units of capital will be identical at $F$ and $G$, by construction. Equally, the identity of capital-labour ratios at $F$ and $G$ implies that the hypothesized withdrawal of $E F$ units of American capital and importation of $E G$ units of Mexican labour is a feasible immigration policy for America since it leaves American capital at its original endowment while paying Mexican labour its marginal product in Mexico. Therefore, an immigration policy, which produces the single good with one technique and the same factors of production while paying Mexican labour the same amount as in the two-technique solution just discussed, should do better for America. And, if Mexican labour import is varied optimally around $E G$ (which was not optimally chosen, of course), there should be still further gain. Hence, it is evident that the policy of optimal taxation of labour inflow dominates the policy of optimal taxationcum-restriction of capital outflow by capital-rich America.

\subsubsection{Perfectly-discriminating tax policy}

Yet another policy may be considered, which taxes away all the gains from Mexican labour inflow by taxing in a 'perfectly discriminatory' fashion. Thus, in fig. 3, assume that America can tax each Mexican labourer to extract the full difference between his American marginal product (=wage) and his Mexican marginal product (=wage forgone).

In that case, the entire world gain $W Y N$ from the Mexican labour inflow will accrue to America and the Mexican non-migrant population will suffer a loss equal to wages earned in America by the migrants. By reference to fig. 1, we can readily see that the world resource allocation will shift from $E$ to (Pareto-efficient) $D$, the world gain will be $R S$, the American gain will also be $R S$, and the Mexican gain will be zero.

The results of these two types of discriminatory-taxation policies are presented in table 3 .

Table 3

Discriminatory tax policies on labour inflow.

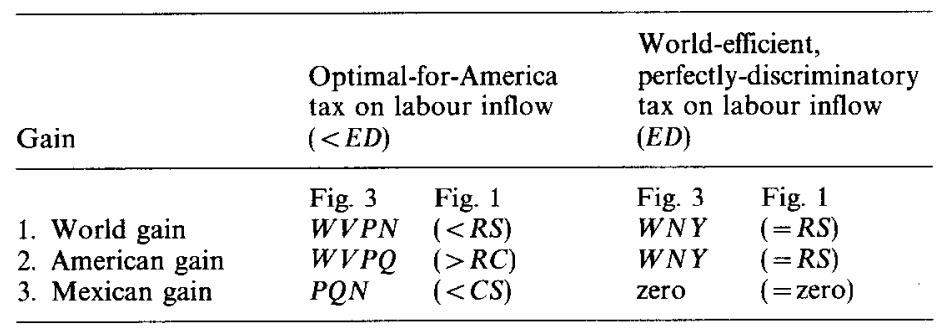




\subsection{Rank-ordering of alternative policies}

From the viewpoint of American advantage, therefore, we get a remarkable and strong rank-ordering of policies: perfectly-discriminatory tax on labour inflow $>$ optimal tax on labour inflow $>$ optimal tax-cum-restriction on capital outflow $>$ free factor mobility $>$ restriction on labour inflow. Of this rankordering, it is the dominance of the optimal tax on labour outflow over the optimal tax on capital inflow that Ramaswami (1968) established.

\section{Immigrants' welfare not necessarily part of only foreign welfare}

The analysis so far has assumed that Mexican migrants' welfare continues to be part of only Mexican welfare. We must however address a few pertinent remarks to the possibility where this is not the case. Thus, the Mexican migrants' welfare may be regarded as part of American welfare. [We should also reckon with the possibilities that the migrants' welfare is not counted in either Mexican or American welfare, and that alternatively (in a benign world) it is considered by American and Mexican policymakers to be part of both rather than neither!] Simply to illustrate the differences in conclusions that can arise, once these considerations are introduced, we focus here on the case where the Mexican migrant labour becomes part of American welfare (as indeed it unambiguously would if, after the 5-year residence requirement, naturalization ensued).

The basic difficulty that this change of assumption about the national characterization of initially Mexican labour makes is that the different policy rankings that we considered in the section 2 are no longer welfarecomparable, without added assumptions, since the population over which they are defined will generally differ. Thus, the capital-export policies will involve the initial American population; whereas the labour quota and taxation policies will each result in different levels of immigration of Mexican labour and hence of the American population. Given this problem, the analyst has no option but to settle for welfare criteria such as the resulting per capita income level under alternative policies, or some explicit cardinal weighting of the different individuals under the different policy options.

Thus, consider the per capita income criterion and focus on American advantage to see how the rank-ordering of our policies can change from that derived in section 2. Turning to fig. 1 , it is then easy to see that free factor mobility, to any point on the diagonal stretch $D D^{\prime}$, will yield an identical per capita income level so that all points on $D D^{\prime}$ continue to be weakly-ranked. However, the optimum optimorum perfectly-discriminating tax policy on Mexican labour inflow is no longer superior to the policy of free factor mobility since the fact that it transfers the gains from the Mexican migrants to pre-migration American natives is no longer an advantage! 


\section{References}

Baumol, William, 1982, The income distribution frontier and the taxation of migrants, Journal of Public Economics 18, no. 3, 343-361.

Bhagwati, Jagdish, 1978, International migration of the highly skilled: Economics, ethics and tax arrangements, Third World Quarterly, June.

Bhagwati, Jagdish N., 1979, International factor movements and national advantage, The 9th Ramaswami Lecture, Indian Economic Review 14 (N.S.), 73-100.

Bhagwati, Jagdish N., 1982, Introduction: Symposium on income taxation in the presence of international personal mobility, Journal of Public Economics 18, no. 3, 285-289.

Bhagwati, Jagdish N. and Koichi Hamada, 1982, Tax policy in the presence of emigration, Journal of Public Economics 18, no. 3, 291-317.

Bhagwati, Jagdish and Martin Partington (eds.), 1976, Taxing the brain drain: A proposal (North-Holland, Amsterdam).

Bhagwati, Jagdish, V.K. Ramaswami and T.N. Srinivasan, 1969, Domestic distortions, tariffs, and the theory of optimum subsidy: Some further results, Journal of Political Economy 77, 1005-1010.

Brecher, Richard, 1983, Second-best policy for international trade and investment, Journal of International Economics 14, this issue.

Calvo, Guillermo and Stanislaw Wellisz, 1983, International factor mobility and national advantage, Journal of International Economics 14, no. 1/2, 103-114.

Johnson, Harry, 1953-54, Optimum tariffs and retaliation, Review of Economic Studies 21 (2), no. $55,142-153$.

Jones, R.W., 1967, International capital movements and the theory of tariffs and trade, Quarterly Journal of Economics, February, 1-38.

Kemp, Murray, 1966, The gain from international trade and investment: A neo-Heckscher-Ohlin approach, American Economic Review, September.

Mirrlees, James $\Lambda ., 1982, \Lambda$ theory of taxation and migration, Journal of Public Economics 18, no. 3, 319-341.

Ramaswami, V.K., 1968, International factor movements and the national advantage, Economica $35,309-310$.

Ramaswami, V.K., 1970, International factor movements and the national advantage: Reply, Economica 37.

Scitovsky, Tibor de, 1942, A reconsideration of the theory of tariffs, Review of Economic Studies 9 (2), 89-110.

Webb, L.R., 1970, International factor movement and national advantage: Comment, Economica $37,81-84$.

Wilson, John D., 1982a, Optimal linear income taxation in the presence of emigration, Journal of Public Economics 18, no. 3, 363-379.

Wilson, John D., 1982b, Optimal income taxation and migration: A world welfare point of view, Journal of Public Economics 18, no. 3, 381-397. 